\title{
CINE EN DICTADURA. NOTAS ACERCA DE LA REPRESENTACIÓN DE LA POBREZA EN CINCO PELÍCULAS CHILENAS
}

\author{
Cinema in dictatorship. Notes about of the representation of poverty \\ in five Chilean films
}

\section{RESUMEN}

El propósito de este artículo es analizar la representación cinematográfica de la pobreza en cinco películas chilenas realizadas durante la dictadura militar del general Augusto Pinochet. Específicamente reflexionaremos acerca del modo en que esas representaciones audiovisuales contribuyeron a suministrar un saber/poder respecto de la inscripción cultural del pobre, la marginalidad y lo popular intentado pesquisar la relación -compleja y no exenta de tensiones- que se establece entre contexto político (dictadura, represión, neoliberalismo) e imagen audiovisual (estereotipos, imagen, representación, estética). A través del análisis de las representaciones y los discursos audiovisuales sobre los pobres durante este período, queremos acercarnos a las implicancias ideológicas de esas imágenes de la marginalidad, e intentar comprender hasta qué punto funcionan como dispositivos de subjetivación de lo popular.

Palabras claves: Cine chileno, marginalidad, pobreza, sujeto popular, dictadura militar, neoliberalismo.

Artículo recibido el 7 de marzo de 2019.

Aceptado el 2 de mayo de 2019. 


\begin{abstract}
The intention of this article is to analyze the cinematographic representation of the poverty in five Chilean movies realized during the military dictatorship of general Augusto Pinochet. Specially we will reflect about the way in which these audio-visual representations contributed to provide a knowledge/power regarding the cultural inscription of the poor, the marginality and the popular, trying to investigate the relationship -complex and not free of tension- that exists between political context (dictatorship, repression, neoliberalism) and audiovisual image (stereotypes, image, representation, aesthetics). Through the analysis of the representations and the audiovisuals discourses about the poor during this period, we want to approach the ideological implications of these images of marginality, and try to understand to what extent they function as devices of subjectivation of the popular.
\end{abstract}

Keywords: Chilean cinema, marginality, poverty, popular subject, military dictatorship, neoliberalism.

\title{
INTRODUCCIÓN
}

El objetivo de este artículo es analizar la representación fílmica de la pobreza en cinco películas chilenas realizadas durante la dictadura militar del general Augusto Pinochet. Específicamente nos esforzaremos por reflexionar acerca del modo en que esas representaciones audiovisuales contribuyeron a suministrar un saber/poder respecto de la inscripción cultural del pobre, la marginalidad y lo popular intentado pesquisar la relación -compleja y no exenta de tensiones- que se establece entre contexto político (dictadura, represión, neoliberalismo) e imagen audiovisual (estereotipos, imagen, representación, estética). Queremos conocer a través de las representaciones y los discursos audiovisuales de este período, cómo fueron representados cinematográficamente los pobres, cuáles son las implicancias ideológicas de la representación de la marginalidad, e intentaremos comprender hasta qué 
punto esas representaciones funcionan como dispositivos de subjetivación de lo popular.

Esta inquietud conlleva, necesariamente, una doble articulación (una desprendida de la otra); pues, por una parte, es fundamental empaparse de las instancias históricas que desde la consolidación de la modernidad han contribuido en la conformación y percepción social de la pobreza. Por otro lado, de esas instancias históricas se desprende un segundo aspecto que dice relación con el modo en que la pobreza se expresa en términos culturales, discursivos y comunicacionales dentro de un contexto social, político y cultural particular. Es este segundo aspecto del fenómeno el que aquí nos interesa estudiar en profundidad; es decir, queremos examinar hasta qué punto el contexto histórico condiciona (o no) la formación de unos discursos y unos saberes que se integran a la representación fílmica de la pobreza, e instalan unos modos de ver y hacer entender lo que Oscar Lewis (1980) 1lamó en su momento una cultura de la pobreza.

Por consiguiente, entendemos aquí que la representación de la pobreza expresada audiovisualmente se encuentra clasificada, delimitada y, hasta cierto punto, definida por un conjunto de prácticas y saberes específicos "que, discursivamente, vuelven nominables esas realidades, las describen, las aíslan, las clasifican y las ponen en relación con otras figuras en el orden del discurso" (Brunner, 1978: 3).

Sostenemos que para el período de la dictadura militar la figura audiovisual de la pobreza muestra cuatro grandes modos de fabricación: una caracterizada por películas que se configuran como expresiones residuales del cine político de los años sesenta, evidenciando una continuidad fragmentaria con aquel período; cintas como A la sombra del sol (1974) de Silvio Caiozzi y Pablo Perelman, o Hechos consumados (1986) de Luis Vera, que manifiesten un cuestionamiento crítico, más o menos indirecto respecto de la dictadura y del modelo neoliberal que se estaba instaurando. En el otro extremo encontramos una cinematografía, Todo por nada (1989) de Alfredo Lamadrid, que distribuyó una nueva estética e imaginario - que se desprende de la hegemonía televisivay que a grandes rasgos manifiesta la internalización de la ideología neoliberal 
y, con ello, se contribuye en la inscripción de una mirada y un entendimiento despolitizado de la pobreza y la subjetividad popular. Entre estos dos polos emerge una cinematografía, Sussi (1988) de Gonzalo Justiniano, que se constituye como como una síntesis de estos dos extremos, puesto que por una parte expresa un discurso contrario en términos políticos a la dictadura y, por el otro lado, manifiesta la internalización de ciertos patrones culturales impuestos por el neoliberalismo autoritario. Finalmente, vemos emerger un cine de autor, El Zapato Chino (1979) de Cristián Sánchez, que pretende instalar un refinamiento de la significación cinematográfica que, mediante una hipercodificación de las imágenes y los signos, no solo complejiza el relato sino también se vuelve un discurso comunicativamente hermético. Nuestra hipótesis plantea que tanto en las películas que minimizan las inequidades de la pobreza como en aquellas que las visibilizan de manera crítica, o bien aquellas que asumen una pretensión artística, tienen el común denominador de definir y clasificar a los pobres como alteridad liminal; entendida esta como la inscripción de una subjetividad imprecisa, que fija al pobre como un Otro u Otra que se encuentra en un perpetuo estado de transitoriedad ${ }^{1}$, y por lo tanto, fuera de los mecanismos que organizan y hacen funcionar los sistemas de clasificación hegemónicos, que habitualmente establecen posiciones predefinidas en el espacio social y cultural, de modo que los pobres producto de su condición social se constituyen como objeto de enunciado y no como

1 La alteridad hace referencia a la pregunta antropológica por la diferencia. Al constatar la existencia cultural de seres humanos que pertenecen a una colectividad distinta a la propia, y que exhiben usos y costumbres, formas de vida, instituciones y conocimientos que difieren unos de otros, la antropología contribuye a la confección en una cartografía cultural en la que se expresa la diversidad como una otredad. Esta constatación contribuye al reconocimiento de las diferencias culturales, las cuales favorecen la emergencia de identidades colectivas y al mismo tiempo manifiestan-a través de los intercambios, las hibridaciones, las resignificaciones culturales, la inexistencia de una pureza cultural (Krotz, 2002). Por otro lado, de acuerdo con Víctor Turner (1988), los sujetos están sometidos a una estructura espaciotemporal tripartita: preliminar, liminal y posliminal. "La liminalidad hace referencia a un estado intermedio, ambiguo e indeterminado; una especie de pasaje (o rito de paso) en el que los sujetos están en un estado indefinido. (Los entes liminales no están ni en un sitio ni en otro; no se les puede situar en las posiciones asignadas y dispuestas por la ley, la costumbre, las convenciones y el ceremonial" (Turner, 1988: 102). 
sujetos de enunciación.

Para dar cuenta de nuestra hipótesis utilizaremos una perspectiva relacional que pretende vincular críticamente discurso audiovisual y contexto histórico. Se trata de una mirada que busca comprender específicamente las relaciones que se establecen entre estética cinematográfica, dictadura, neoliberalismo y pobreza. Por lo tanto, entendemos que el cine se articula como una estética que lleva inscrito "un modelo de sociedad, que traspone el ámbito de lo real o podría traducirse en él” (Bourriaud, 2013: 139). Entendemos que las películas que aquí analizaremos producen y reproducen un criterio de coexistencia entre realidad objetiva y realidad imaginada y, en esa convivencia, se expresan un conjunto de prácticas, saberes, discursos e imágenes, "que toman como punto de partida teórico y práctico el conjunto de las relaciones humanas y su contexto social" (Bourriaud, 2013: 142). A partir de esta mirada relacional se puede inferir el modo en que el discurso audiovisual del período dictatorial contribuye -en conjunto con otras expresiones, discursos y prácticas culturales-al proceso de transformación y ordenamiento de la pobreza en cultura singularizada. Se trataría de un proceso de inscripción que vuelve figurable al pobre y su condición de pobreza $\mathrm{y}$, desde ese trabajo de figurabilidad audiovisual, nos permite

\footnotetext{
"pensar el estatuto de visibilidad -o de invisibilidad- [de la pobreza] (...) [puesto que], no sólo se inscriben [audiovisual y] subjetivamente a través del régimen significante que organiza su discursividad, admitiendo desde ahí su eventual interpretación, sino que organizan un espacio donde lo visible y lo enunciable se articulan recíprocamente" (Aceituno, 2012: 15).
}

Pensar en el cine como un espacio de figurabilidad de la pobreza, es pensar en el ordenamiento eficaz que tiene del cine para fabricar un espacio simbólico, audiovisualmente constituido y legitimado, que organiza y conforma visibilidades y discursos que instituyen significativamente modos de ver y hacer ver la pobreza. De ahí que "cada estrato, cada formación histórica implica una distribución de lo visible y de lo enunciable que se produce en ella" (Deleuze, 1987a: 76). Es precisamente esa distribución de 
signos audiovisuales que conforman un régimen significante de visibilidad, el que hace figurable determinados saberes sobre la pobreza e instaura un estrato de visibilidad compuesto "de cosas y de palabras, de ver y de hablar, de visible y de decible, de superficies de visibilidad y de campos de legibilidad, de contenidos y de expresiones" (Deleuze, 1987a:75).

Entendemos, entonces, que el cine realizado en dictadura conforma un estrato en donde lo visible y lo enunciable fundan capas de visibilidad en el que tienen lugar un conjunto de inscripciones, representaciones e ideologías que, a través de la narrativa fílmica codifican la pobreza y, en ese proceso de codificación tienen lugar formas y maneras específicas de hacer pensar e imaginar los espacios sociales, las prácticas culturales, los estilos de vida, los juicios y prejuicios adosados a la imagen del pobre y su pobreza, subrayando cualidades particulares que hacen legible, es decir, entendible la pobreza, a través de representaciones que le confieren al sujeto popular una imagen dentro de una época y un contexto histórico particular. La historicidad de las imágenes cinematográficas emerge como un síntoma, como una evidencia que se articula como un índice histórico de las imágenes cinematográficas, donde "el conocimiento histórico no acontece sino a partir del ahora, es decir, de un estado de nuestra experiencia presente del que emerge, de entre el inmenso archivo de textos, imágenes o testimonios del pasado, un momento de memoria y legibilidad" (Didi-Huberman, 2015a, pp. 19-20).

\section{PRODUCCIÓN SIMBÓLICA Y LA DOCTRINA DE SEGURIDAD DEL ESTADO}

El golpe de Estado "se presenta a sí mismo como un gran acto ordenador" (Brunner, 1988: 90); que persiguió destrozar todos los esquemas de racionalidad y sentido que desde la izquierda se habían logrado instalar a partir del triunfo de la Unidad Popular, y que a grandes rasgos hizo del pueblo y lo popular una categoría política significativa. El gran mito ideológico de la dictadura fue el de articular un discurso político que se justificó, primero, como una respuesta a la necesidad de reconstruir el país después 
del "cáncer marxista", para luego ensalzar un proceso de modernización que puso al mercado financiero como el gran motor de la modernización. Los aparatos ideológicos de la dictadura instalaron la idea de que a mayor mercantilización de las esferas socioeconómicas (flexibilidad laboral, apertura económica, precarización laboral, etc.) y socioculturales (trabajo, diversión, vida cotidiana, etc.), más intenso sería el proceso de modernización del país (Mayol y Ahumada, 2015). Esta hipótesis modernizadora se sustentó sobre un conjunto de transformaciones políticas e institucionales conocida como "Las Siete Modernizaciones” y que, a grandes rasgos, apuntó a transformar drásticamente siete áreas clave de la sociedad chilena: la política laboral, la educación, la salud, la seguridad social, la descentralización regional, el aparato judicial y la agricultura (Foxley, 1982).

Dentro del contexto dictatorial la producción simbólica estuvo condicionada tanto por criterios mercantiles como por la Doctrina de Seguridad del Estado, que en un primer momento se constituye como un dispositivo de violencia y disciplinamiento que tuvo por finalidad desactivar y desmovilizar al movimiento popular, y para ello, se lleva a cabo un acto de ordenamiento y limpieza a través de los aparatos represivos del Estado. En una segunda fase la represión se institucionalizó como dispositivo de coerción y disciplinamiento de la sociedad, que tuvo por función mantener libre de obstáculos el desarrollo del nuevo modelo socioeconómico. Así el Estado se transformó “en el brazo armado de la clase dominante" (Brunner, 1981: 51). Esto implicó la instalación de todo un entramado autoritario que justificó la represión, la tortura y la desaparición forzada de personas, llevando "los procedimientos biopolíticos (...) al punto extremo de su poder coercitivo, imprimiéndoles [a la sociedad chilena] un vuelco tanatológico" (Esposito 2011: 176). En tal sentido, la doctrina de seguridad se configuró como un dispositivo biopolítico que vino a dar respuesta "a los principales problemas de la fase de implementación del nuevo patrón de dominación, incorporándose progresivamente, en los años siguientes, a la concepción autoritaria del mundo" (Brunner, 1981: 51).

Nos parece necesario señalar que la doctrina de Seguridad del Estado transciende su carácter represivo, y se configura como un aparato ideológico 
que asume las metas autoimpuestas por la burguesía financiera y las fuerzas armadas, de modo "que la seguridad nacional se convierte en una condición de posibilidad del desarrollo capitalista en Chile" (Brunner, 1981: 52). Por lo tanto, la ideología de la seguridad, al reprimir las movilizaciones sociales, al coartar la libertad de expresión, al domesticar la subjetividad colectiva a fuerza de represión y tortura, facilitó el camino para la emergencia del neoliberalismo, el cual se irá instituyendo progresivamente como racionalidad que justifica el uso discrecional del poder represivo y así poder mantener el orden y generar las confianzas necesarias para la inversión del gran capital financiero; pero al mismo tiempo instala sobre el campo social una gubernamentalidad neoliberal autoritaria, que fue extremadamente eficiente en asentar una visión de mundo "que vino a sustituir una antigua matriz político-céntrica o nacional popular cuyo rasgo más sobresaliente fue la integración de la sociedad alrededor del Estado, los partidos políticos y los actores sociales" (Araujo y Martuccelli, 2012: 29); y estableció una matriz político-mercantil que facilitó el camino para la fabricación del homo neoliberal. Araujo y Martuccelli plantean que la primera aproximación que realiza la dictadura militar para fabricar un homo neoliberal es de índole abiertamente política. Esto queda graficado en el discurso refundacional que hace el régimen militar del golpe de Estado de 1973. De modo que la producción de un nuevo tipo de sujeto se funda:

a través de un tenaz combate ideológico, un combate que debía, por un lado, imponer un relato histórico hegemónico sobre el pasado, sus excesos y sus males y, por el otro, producir la adhesión de los individuos a los grandes pilares valóricos del modelo. Uno y otro objetivo suponiendo, primero, la desmovilización política de la sociedad, luego, la privatización de los individuos (Araujo y Martuccelli, 2012: 35).

La tesis de Araujo y Martuccelli sugiere que el proyecto del homo neoliberal chileno no es tanto un relato hegemónico del pasado, sino más bien muestra una diversidad de lecturas muchas veces en conflicto y, particularmente, plurales respecto de las significaciones personales que este nuevo sujeto ha implicado en la conformación de subjetividades y discursos 
que se desprenden de la gubernamentalidad neoliberal.

Ahora, dentro del contexto dictatorial el proceso represivo y la intervención gubernamental en el ámbito de la producción cultural muestra que los sistemas simbólicos (arte, medios de comunicación, campo intelectual, etc.), entran en una fase de retraimiento y decadencia que, se conoce como "apagón cultural", entendido este como la escasa producción y circulación de productos artístico-culturales, y como el estricto control, censura y represión que se llevó a cabo sobre los agentes culturales y sus obras. Si bien todo el campo cultural se vio sometido al flujo de la maquinaria dictatorial, la producción cinematográfica fue inmediatamente sometida a los dispositivos de desmantelamiento, destrucción y pérdida del patrimonio audiovisual chileno. Así, el mismo día del golpe militar, los estudios de Chilefilms son asaltados por tropas militares, quienes destruyen laboratorios, instalaciones y durante tres días se enfocan en la tarea de quemar miles y miles de metros de material fílmico, con el pretexto de destruir cualquier manifestación audiovisual que pudiera oler a marxismo (Mouesca y Orellana, 2010).

El cine chileno del período transitó por varios caminos, desde un cine de exilio, desarrollado por todos aquellos cineastas que se vieron obligados a abandonar el país, pasando por la escasa producción nacional hasta una cinematografía de los retornados. La investigadora María de la Luz Hurtado (1985) ha mostrado la existencia de dos grandes períodos del cine desarrollado en dictadura: uno que califica como "desarticulación”, que a grandes rasgos implicó la desaparición casi total de la producción argumental y documental y que va desde septiembre de 1973 hasta finales de 1977. En esta fase vemos el desmantelamiento de las instituciones del Estado destinadas a la producción cinematográfica. Por una parte, se desmonta Chilefilms, empresa creada en 1942 y que bajo el alero de la Corporación de Fomento de la Producción (CORFO) "tenía por objetivo colaborar y fomentar el desarrollo de proyectos fílmicos a través de la asignación de créditos, así como contribuir con las instalaciones y equipos técnicos" (Donoso, 2013: 125). Por otro lado, vemos la feroz intervención en las universidades, que hasta septiembre de 1973 eran las responsables tanto de la formación de cineastas como de la realización de 
películas, de modo que la clausura de las carreras de cine en la Universidad de Chile, la Universidad Técnica del Estado y la Pontificia Universidad Católica de Chile son el síntoma de este proceso de desarticulación de la producción cinematográfica (Mouesca, 1998). El caso de Chilefilms es paradigmático, principalmente, porque pasó a depender institucional y administrativamente de Televisión Nacional de Chile, y ello implicó ponerle una lápida al cine nacional, ya que se privilegió potenciar la televisión como dispositivo de entretenimiento y comunicación masiva (Corro, 2012).

La segunda fase que identifica María de la Luz Hurtado (1985) es la de "recomposición" que ella sitúa a partir de 1978. Esta recomposición tiene más que ver con el video y la televisión y no tanto con la producción cinematográfica² Por lo tanto, lo que se recomponen es la producción televisiva, principalmente aquella que se desprende de Televisión Nacional como el gran escaparate de la dictadura. Por otro lado, la publicidad "se transforma (...) en la base esencial del sustento del sistema televisivo" (Mouesca y Orellana, 2010: 146), es el lugar en donde cineastas y productores puedan subsistir laboralmente.

Lo que nos parece relevante de este proceso de recomposición del audiovisual, es que ello implicó la consolidación de la institucionalidad televisiva para la producción y distribución de contenidos audiovisuales, de modo que, tanto el campo televisivo como el publicitario contribuyen en "el negocio de identificar y crear consumidores, de moldear y dar satisfacción a las apetencias imaginarias" (Corro, 2012: 88). Es en este punto donde

2 Si entre 1967 y 1973 se realizaron 15 largometrajes de ficción que fueron exhibidos en salas de cine comercial; con el golpe de Estado de 1973 el apoyo estatal a la producción cinematográfica desaparece por completo y entre 1974 y 1984 se contabilizan 4 largometrajes que fueron estrenados comercialmente; entre 1985 y 1989 se producen 9 largometrajes de ficción de los cuales 8 fueron estrenados en salas comerciales; estas cifras contrastan ampliamente con el cine de exilio que muestran para el período 1973-1983 la nada despreciable suma de 53 largometrajes, 34 mediometrajes y 86 cortometrajes (Brunner, Barrios y Catalán, 1989). Es evidente que esta diferencia entre la producción nacional y la del exilio se debe, entre otros factores, al hecho que los cineastas exiliados llegaron mayoritariamente a países que contaban con un sistema industrial de producción y distribución de películas, apoyado tanto por el Estado como por la iniciativa privada, lo cual marca una diferencia significativa con un país sumido en una dictadura que veía en la producción cinematográfica un incordio al cual había que controlar. 
neoliberalismo, dictadura y audiovisual se conjugan para domesticar la escena audiovisual e inscribir sobre las subjetividades una razón neoliberal que tiende a despolitizar y singularizar a los sujetos que, hasta el 11 de septiembre de 1973, al menos en el imaginario del arte y la producción cultural, se encontraban colectiva y políticamente constituidos.

En consecuencia, el quiebre dictatorial y la imposición de un escenario socioeconómico neoliberal, vino a desintegrar los antiguos proyectos de representación ideológica, lo cual trajo como resultado la instalación de un nuevo sistema de dominación cultural que plasmó una ideología donde "la posibilidad de elegir equivale a la de imaginar un lugar de pertenencia y reconocimiento anclado en la compra" (Blanco, 2012: 34). Esto tiene como resultado la segmentación social, la despolitización de la sociedad y la consecuente privatización de lo público, que contribuye en la estructuración de una sociedad que opera bajo la lógica de las esferas separadas, y que favorece "la constitución de una sociedad dual, estructurada a dos velocidades y que coagula en un verdadero apartheid social" (Boron, 1999: 97).

\section{LA PRODUCCIÓN CINEMATOGRÁFICA DE LA POBREZA}

Pese al férreo control y censura que se ejerció sobre la producción simbólica, paradójicamente encontramos, que la primera película chilena estrenada comercialmente en dictadura es una cinta que es heredera del cine político de la Unidad Popular. Se trata de la película $A$ la sombra de sol de Silvio Caiozzi y Pablo Perelman, que el 28 de noviembre de 1974 se estrenó en el cine Las Condes de Santiago. Después del estreno, dos miembros del equipo de producción, Carmen Bueno (24 años) y su pareja Jorge Müller (27 años), fueron detenidos por los servicios de seguridad de la dictadura y ambos engrosaron la lista de detenidos desaparecidos. La película de Caiozzi y Perelman se inscribió en la historia del cine chileno como un síntoma que evidencia una doble tragedia política, la caída de la "vía chilena al socialismo" y la desaparición forzada de sus colaboradores (Gallardo, 2007).

El quiebre dictatorial inscribió A la sombra del sol como una cinta 
en la que "quedó registrado el gesto de un modo expresivo y cultural que había llegado a su fin" (Gallardo, 2007: 125). De ahí que la cinta de Caiozzi y Perelman puede ser vista como "una obra de carácter residual, anacrónica, con relación al contexto histórico de su realización y circulación" (Gallardo, 2007: 131). El anacronismo en esta película puede ser analizado, siguiendo a Didi-Huberman, a partir de una cierta "virtud dialéctica (...) [puesto que] el anacronismo parece surgir en el pliegue exacto de la relación entre imagen e historia" (2015b: 48). Al utilizar como centro discursivo el tema de la justicia popular, la cinta de Caiozzi y Perelman se constituye como un síntoma anacrónico de su tiempo que escapa a la historicidad de la dictadura. La problemática de la justicia popular no solo ordena la trama y las acciones de los protagonistas, donde todo lo que antecede al juicio popular y su desenlace, está organizado en términos narrativos y diegéticos para la consumación del instante decisivo donde el pueblo, en tanto colectivo consciente, asume la dificultosa tarea de impartir justicia; sino también como una problemática donde la justicia popular y su temporalidad puede ser reconocida como tal, en la medida en que la historicidad de la dictadura militar es dialectizada por el elemento anacrónico de la justicia popular que instala, discursivamente, una imagen de poder que no aparece en la historia más que como un síntoma (Didi-Huberman, 2015b).

Si bien la pobreza no es un asunto central, si nos parece significativo el modo en que se representa a los sujetos populares. Al respecto, A la sombra del sol construye un relato bipolar que enfrenta al bien (comunidad) con el mal (delincuentes); una oposición binaria que se va desplegando dentro de la trama primero como hospitalidad, diálogo y participación en la vida social de la comunidad, luego como violencia, trasgresión de las normas, violación y restitución del orden alterado. Al poner en pantalla dos representaciones del sujeto popular que se contraponen, se establece un antagonismo que inscribe una subjetividad popular doblemente articulada. Por un lado, al instituir a un sujeto popular comunitario, consciente de su realidad social y de su devenir histórico, se instala un discurso que logra pronunciar un punto de vista político que visibiliza prácticas y modos de actuar, que intervienen ellas mismas, en 
lo que Jacques Ranciére (2009) llama el reparto de lo sensible, idea que refiere a las diversas formas en que la producción simbólica distribuye y hace visible representaciones acerca del modo en que los sujetos participan en la cosa pública y en los procesos de producción de sentido de acuerdo a los variables posicionamientos que ocupan según su clase, género, etnia, etc. Por el otro lado, se fabrica a un sujeto popular antagonista cuya subjetividad se encuentra recluida sobre sí misma. Al inscribir al lumpen como singularidad despolitizada, la película de Caiozzi y Perelman teje una segunda versión de lo popular en la que lo comunitario, lo social y el colectivo solo tienen valor o interés en la medida en que satisface la individualidad del delincuente.

A la sombra del sol distribuye dos versiones contrapuestas del sujeto popular, una que instaura discursiva y audiovisualmente al sujeto popular y al pueblo como unidad orgánica, y con ello se instituye el espacio de lo común, del colectivo consciente de su historia y su devenir; se fabrica de este modo a un pueblo y una subjetividad popular anacrónica a su tiempo histórico y, por ello utópica. El otro sujeto popular que cohabita en la película es el reverso antagónico de ese pueblo consciente, es la positivación de una subjetividad delincuencial que instituye la imagen y el discurso del individuo agenciado sobre su propia individualidad, al cual se le atribuyen un conjunto de características que, unidireccionalmente, operan sobre la base de atributos y estereotipos que funcionan como marcajes de sentido que tienden a naturalizar formas de ver y hacer entender la condición de la pobreza.

La cinta El zapato chino (1979) de Cristián Sánchez es una narración críptica, que busca metaforizar el viaje a la locura de Andrés, un taxista que ha perdido la razón producto de la pasión que siente por Marlene, una joven provinciana que trabaja en un burdel. El taxista, poco a poco va siendo dominado, primero por un afán de proteger a la muchacha, luego por una pulsión sexual hacia la joven que lo termina sumiendo en una espiral de locura. De acuerdo con Sánchez (2007), el cine que él intentaba realizar durante la época de la dictadura era "un cine trasgresor, en cierto modo político, pero disfrazado" (Ruffinelli y Sánchez, 2007: 56). Con El zapato chino, Cristián Sánchez quería "reflejar de una manera indirecta esta situación de represión, 
de violencia, de supresión de todo" (Ruffinelli y Sánchez, 2007: 66).

Sin embargo, a nuestro modo de ver, El zapato chino no logra plasmar discursivamente su intención política, puesto que al concentrase en el lado inconsciente, onírico y surrealista de los protagonistas, la cinta privilegia una construcción fundada en lo que lo que Gilles Deleuze (1987b) llama narración cristalina $^{3}$, esto es, se privilegia una descripción discontinua, fragmentaria y abstracta, que persigue desarticular aquellos esquemas narrativos en donde los personajes responden a situaciones, y las situaciones responden a contextos históricos. De este modo, la película de Sánchez descontextualiza no solo la atmósfera dictatorial, sino también la condición de pobreza y decadencia de los protagonistas. La hipercodificación de los enunciados inscritos en la película de Sánchez requieren una arqueología compleja para desenterrar las significaciones enmascaradas, y así poder desclasificar la compleja alegoría política que El zapato chino pretende presentar, y que de acuerdo con Valeria de los Ríos, implica entender que "la política en [el cine de] Sánchez más que un discurso de resistencia o la exhibición del sujeto 'pueblo', se configura como un lugar de enunciación y como una estrategia retórica" (2014: 181).

3 Gilles Deleuze, contrapone dos regímenes de la imagen: uno que llama orgánico y el otro que denomina cristalino. El primero dice relación con lo cinético y tiene que ver con las descripciones en donde hay una dependencia o correlación entre imagen, descripción y objeto. "No se trata de saber si el objeto es realmente independiente; no se trata de saber si se trata de exteriores o de decorados. Lo que importa es que, decorados o exteriores, el medio descrito esté planteado como independiente de la descripción que la cámara hace de él, y que valga para una realidad que se supone preexistente" (Deleuze, 1987b: 171). Mientras que lo cristalino implica la creación de una imagen que de alguna u otra manera crea el objeto representado, "es la propia descripción la que constituye el único objeto descompuesto, multiplicado" (Deleuze, 1987b: 171). Por otro lado, estos dos regímenes no solo operan en el orden de la descripción sino también divergen en la manera en que conforman sus respectivas narraciones. Así, por ejemplo, la narración orgánica opera de acuerdo con el desarrollo de esquemas donde los personajes responden a situaciones de causa-efecto que tiene por finalidad instalar una narración verídica y realista. "Es un régimen complejo, porque puede involucrar rupturas (elipsis), inserciones de recuerdos y sueños, y sobre todo porque implica determinado uso de la palabra como factor de desarrollo" (Deleuze, 1987b: 173). La narración cristalina implica una transformación del esquema señorial de causa-efecto que involucra el realismo y la verosimilitud de aquello representado con la realidad, de modo que "las situaciones sensoriomotrices han dado paso a situaciones ópticas y sonoras puras ante las cuales los personajes, ahora videntes, ya no pueden o ya no quieren reaccionar" (Deleuze, 1987b: 174). 
Esta retórica del hacer aparecer por medio de la ausencia, por medio de un lenguaje que dice sin decir, de imágenes que muestran sin mostrar, corre el riesgo de construir una alegoría donde nada es lo que parece, y donde lo que aparece termina por socavar la crítica que se pretende poner en escena. Esto porque el relato de Sánchez se desvanece bajo una representación sin código, sin referencia, donde los sujetos y sus diversos vínculos y relaciones de poder quedan suspendidos o deambulan bajo una representación fantasmagórica “entre lo que se dice y lo que dejamos de ver” (De los Ríos, 2014: 178).

Si en El zapato chino encontramos algunos guiños a la condición de precariedad laboral y de crisis económica, y con ello se pretende dar a entender el problema social que implicó los ajustes de la política economía de la dictadura, esto no quiere decir que la cinta de Sánchez ahonde en esta problemática, por el contrario, pasa superficialmente por ella, ya que la dimensión social se constituye como ausencia, y lo que importa es el individuo y su devenir existencial que se encuentra singularizado. Otra de las ausencias que se destaca en esta cinta, es la construcción de una representación deshabitada de la sociedad: calles sin gentes, personajes sin origen en el sentido genealógico y social. Esta representación de la ciudad, puede ser leída como una alegoría política al estado de sitio que imperaba a fines de los setenta, y responde discursivamente a la contingencia que imponía la censura dictatorial, lo cual implicaba "concebir obras que se repliegan a una zona de prospección más oculta" (Sánchez citado en Soto, 2007: 218); esto traía aparejado la elaboración de películas que requerían un entramado complejo de enunciación que "conlleva el cultivo de un cine de elites" (Soto, 2007: 218).

Si la película El zapato chino nos muestra una subjetividad popular escindida de su condición de clase, y construye una narración que pretende ser cristalina y fragmentaria del mundo popular; la cinta Hechos consumados (1986) de Luis Vera, nos introduce de lleno en el mundo de la marginalidad desde una narración orgánica de causa/efecto, a partir de la cual se quiere cuestionar la crisis económica y las implicancias sociales que trajo consigo la instalación del neoliberalismo autoritario. La película lleva a cabo una crítica al modo en que el neoliberalismo instaló una ideología que sobrevalora la 
propiedad privada por sobre el interés colectivo y, donde la subjetividad del sujeto marginal se configura como una amenaza en la medida en que no ha logrado ser domesticado por la racionalidad neoliberal. Aquí la subjetividad marginal puede ser leída como resistencia política al autoritarismo pinochetista, porque su figura viene a cuestionar algunos de los fundamentos básicos de la lógica neoliberal, que pretende instalar una economía política que pone al mercado como eje estructural y estructurante de la sociedad chilena.

Uno de los elementos interesantes de la película de Vera es la construcción de tres tipologías de sujetos marginales, que se definen a partir de su forma de relacionarse con el poder. Por un lado, está el proletario que se somete al patrón, que hace todo lo que éste le indica y es una suerte de perro guardián de los intereses de la clase dominante, con la esperanza de que eso al menos le permita conservar el trabajo. Otra tipología es la que representa Emilio, el vagabundo que, tras verse expulsado de todos lados, opta por radicalizar su cotidianidad y rechaza cualquier posibilidad de estructurase dentro de los marcos que el orden hegemónico quiere imponerle. Su postura confrontacional constituye un doble riesgo para la clase dominante: "un riesgo de irrupción (real o simbólica) hacia el centro de la sociedad echando de paso abajo los límites exteriores del sistema" (Brunner, 1979: 26); y, en segundo término, se configura como amenaza al orden capitalista porque al no haber podido ser domesticado, "se vuelve peligroso, precisamente, en la medida de su alienación o no-integración respecto de ese orden predominante" (Brunner, 1979: 32). Finalmente, está la figura de Marta, personaje optimista y alegre a pesar de su situación, y que aun cuando se sitúa del lado del vagabundo marginal, intenta actuar como mediadora y provocar la empatía del trabajador que defiende los intereses de la élite.

Más allá de la trama misma, en un segundo nivel de análisis, Hechos consumados pone de relieve que la sociedad en su conjunto le teme a toda persona o comportamiento que rompe las pautas, normas y valores hegemónicos. Y desde esa perspectiva la figura del pobre-marginal puede ser leída como la negación del orden dominante; se trata, si se quiere, de una negación ineficaz o mejor dicho de una negación políticamente inoperante, pese a ello, el marginal 
representa una amenaza y la marginalidad un peligro. En suma, con la película de Vera, los marginales son una representación metafórica de aquellos que siendo los excluidos, los parias del sistema se instituyen como una conciencia social y un devenir que logra plasmar, según la expresión marcusiana, un rechazo absoluto a la lógica del mercado, el individualismo y la propiedad privada.

Hechos consumados hace referencia explícita al contexto económico neoliberal autoritario. Por su parte, la película Sussi de Gonzalo Justiniano, hace referencia al contexto político a través de una serie de gestos mínimos e incluso aparentemente sin vínculo con el relato central. Sin embargo, son gestos que producen lo que Roland Barthes (2001) llamó efectos de realidad, que permiten situar la trama y entender la connotación política del devenir de la protagonista. Estos detalles - cortes de luz, rayados callejeros exigiendo, por ejemplo, “idemocracia ahora!”, agentes de la policía secreta de Pinochet, etc.- van posicionando al filme como un intento de denuncia de los males que afectan a la sociedad chilena. Sin embargo, ese intento crítico es un tanto reduccionista, en la medida en que se construyen clases sociales estereotipadas: la clase alta es egoísta, la clase media arribista y la clase baja solidaria.

Por otro lado, la figura de Sussi se configura como el estereotipo de la mujer popular que escala socialmente gracias a sus atributos físicos. Al ser la belleza de Sussi la cualidad principal posibilita su ascenso social, la cinta de Justiniano reproduce la ideología de la cosificación sexual que inscribe a la mujer como imagen, mientras que al hombre lo sitúa como portador de la mirada (Mulvey, 2001). No deja de ser sintomático el hecho de que sea el cabaré el espacio social donde las diversas clases sociales pueden encontrarse; es allí en donde se plasman las diversas relaciones de poder que la película quiere retratar. Estas relaciones de poder muestran a Sussi, en tanto figura que se subordina al poder de la élite, como una subjetividad dominada de la clase dominante, necesariamente inclinada a formar una imagen ambigua de su posición en la sociedad. Esta ambigüedad tiene que ver con su conversión en un bien de consumo simbólico, una figura homenajeada y encumbrada, que obtiene una serie de beneficios económicos, pero que a 
cambio debe renunciar a su subjetividad popular. Sussi, al convertirse en el rostro publicitario de la nueva mujer chilena, -una especie de síntesis entre Lucía Hiriart y Cecilia Boloco vestida con la capa característica de Pinochetdebe cambiar radicalmente su estilo de vida, no tanto por su origen popular, que a fin de cuenta es lo que la ha llevado a ser elegida la representante de la nueva mujer chilena para la campaña publicitaria del gobierno, sino por una cuestión culturalmente arraigada, que dice relación con el modo en que la dominación masculina se expresa a través de lo que Françoise Héritier llama "la valencia diferencial de los sexos" (2007: 114). Esto se materializa, en la película de Justiniano, al mostrar que la relación hombre/mujer está construida sobre un conjunto de oposiciones binarias arriba/abajo superior/inferior, elite/ popular, moral/inmoral fealdad/belleza, etc. Estos binarismos son utilizados narrativamente para otorgarle al relato una condición de verosimilitud, que viene a reforzar el amplio sistema de clasificación, jerarquización y distinción donde "el polo superior está asociado a lo masculino y el inferior a lo femenino (Héritier, 2007: 115).

Si en términos de representación del contexto político, la cinta de Justiniano se empeña en representar la dictadura a través de gestos mínimos que producen efectos de realidad y, con ello, se quiere plasmar una mirada de resistencia al régimen autoritario; no es tan sutil a la hora de mostrar la emergencia de una razón neoliberal, que hace de la publicidad el gran dispositivo que permitiría a la mujer popular acceder al bienestar material y al reconocimiento social; siempre y cuando, eso sí, esa mujer popular sea cosificada como cuerpo colonizado por la licitud de la pulsión sexual masculina. Tratando de ser justos con la película se podría argumentar que Sussi, de alguna u otra manera, ofrece una mirada crítica a la inmoralidad de la clase dominante que cosifica a la mujer y la reduce a un bien intercambiable en el mercado de los bienes simbólicos.

Sussi se configura como una película que se encuentra a mitad de camino entre lo que hemos definido como películas residuales del cine político de los años sesenta y una cinematografía neoliberal que resalta la individualidad y 
el mercado como dispositivos de socialización. En contraste, la película Todo por nada (1989) de Alfredo Lamadrid, cuya protagonista transita un camino semejante al de Sussi, no hace ninguna referencia al contexto político o social y en ese sentido se trata de una película que podemos clasificar como ideológicamente neoliberal. Esto queda claramente graficado en cómo la cinta naturaliza la emergencia de una nueva burguesía urbana, cuya fortuna no es parte del dinero proveniente de la industria o el campo, sino de la televisión, la publicidad y el modelaje.

Por otro lado, la representación que se hace de la mujer popular se encuentra desvinculada de cualquier contexto social. Si en Sussi, la condición de mujer del pueblo conlleva un atributo al cual sacarle partido, en Todo por nada lo popular no representa ningún tipo de atributo, es más bien una condición neutral, o a lo sumo un detalle que permite situar las aspiraciones de la protagonista. En Todo por nada, la protagonista es la que lleva sus propios asuntos, todo ocurre como desafectado de un contexto social mayor; de modo que la pobreza, la exclusión social e incluso la condición de mujer de la protagonista es siempre una cuestión personal, un asunto que se resuelve en los límites de su pequeño mundo privado.

Uno de los elementos interesantes que surgen producto de la descontextualización del mundo social de Alejandra, la protagonista de Todo por nada, es que su condición social y su deseo de ser una estrella de la televisión producen una paradoja. Por una parte, la privatización de su devenir socialpobreza, amor, dinero y trabajo- se zanjan exclusivamente en la intimidad; mientas que su imagen de mujer es una cuestión que se resuelve en los límites de lo público a través de la exhibición televisiva de lo femenino como cuerpo domesticado por la pulsión sexual masculina. Entre lo público (la mujer como imagen televisiva y como objeto sexual) y lo privado (su devenir social y amoroso), Todo por nada se estructura como una cinta que ideológicamente lleva inscrito lo que Laura Mulvey (2001) llama la manipulación del placer visual en el cine masivo o comercial. Es decir, la condición de objeto sexual de Alejandra es lo que le proporciona su lugar en el mundo y le confiere tanto la posibilidad de desarrollar una carrera televisiva como de encontrar 
el amor. Así, esta condición dual pública/privada, amor/trabajo no responde a una determinación de la protagonista que nos pudiera hablar o mostrar sus miedos o anhelos, sino que en tanto subjetividad dominada, encarna, proyecta y "significa el deseo masculino, soporta su mirada y actúa para él" (Mulvey, 2001: 370). Así, por ejemplo, podemos ver cómo Alejandra que en un principio aparece como glamorosa, dueña de sí misma, sexualizada. Sin embargo, cuando la historia sigue su rumbo y ella se enamora, paulatina e inconscientemente, ella se va transformando en la propiedad del hombre amado, e incluso cuando ella está a punto de lograr su gran anhelo, el de ser una estrella de televisión, ella decide no tomar esa posibilidad y opta por seguir a su enamorado, a quien le han ofrecido un importante trabajo en Europa como fotógrafo.

En consecuencia, aun siendo ella la protagonista de la historia, su presencia visual opera como hilo argumental donde lo que importa no es tanto lo que ella representa como mujer perteneciente a la clase trabajadora, sino que es lo que ella muestra como mujer dotada de ciertos atributos físicos. Se trata de un filme que se estructura bajo la lógica de una escopofilia ligada al placer de un mirar patriarcal. Ello implica que la cinta de Lamadrid, en un punto no menor de su estructura narrativa y diegética, utiliza la figura de las mujeres "como objetos sometiéndolos a una mirada escrutadora y curiosa" (Mulvey, 2001: 367). En tal sentido, la construcción de la subjetividad femenina inscrita en Todo por nada se configura como una representación sexualizada que somete a la mujer a la mirada masculina, que funciona como mecanismo de sujeción y control.

\section{CONCLUSIONES}

En este recorrido por el cine chileno realizado en dictadura hemos querido comprender tanto aquellos aspectos que son transversales a las cinco películas que componen este corpus, como aquellos puntos que le son singulares. Así, por ejemplo, uno de los elementos comunes a todas las películas analizadas es que estas definen y clasifican a los pobres como alteridad liminal. Los pobres aparecen en estas cintas en un constante estado 
de indefinición, están fuera o en los márgenes de los engranajes que ordenan el funcionamiento social impuesto por los sistemas de clasificación dominante. De ahí que la figura del pobre se encuentre atrapada dentro de un estado de ambigüedad e indeterminación que hace de la subjetividad marginal una inscripción fragmentada y dislocada respecto de una estructura narrativa mayor, por lo general hegemónica, que ordena la vida social como una realidad unificada y coherente y a la cual el pobre no puede acceder y, producto de esa clausura, el pobre se encuentra en un perpetuo estado de ambigüedad. Así, por ejemplo, en la película $A$ la sombra del sol, los delincuentes están siempre en un constate tránsito: huyendo de la cárcel, huyendo del poblado que los cobijó. En la película Sussi, la cosificación de la protagonista la lleva a convertirse en una imagen de poder carente de todo poder de decisión. En la cinta El zapato chino, la alteridad liminal se materializa en la figura del taxista enamorado de la joven provinciana y ese enamoramiento lo desestabiliza a tal punto que termina viviendo en el maletero de su taxi. En Hechos consumados vemos cómo los marginales son expulsados de todas partes porque representan un riesgo para la sociedad disciplinaria. En la cinta Todo por nada, vemos cómo Alejandra cuando logra alcanzar su anhelo de ser una figura de la televisión, advierte que el éxito ya no tiene sentido y vuelve nuevamente a un estado de incertidumbre.

Este ordenamiento y clasificación del mundo marginal-popular como alteridad-liminal no es, en ningún caso homogéneo, unidireccional o uniforme; por el contrario, cada una de las películas analizadas para este artículo muestran diversos grados y variaciones respecto de la inscripción fragmentada de la subjetividad popular. Cuando observamos más detalladamente la inscripción ideológica que se desprende en cada una de las cintas que componen nuestros materiales de análisis, encontramos algunas distinciones en el discurso y la representación de la figura cultural del pobre como alteridad liminal, lo cual implica, a nuestro modo de ver, al menos tres grandes momentos o tendencias del cine chileno hecho en dictadura recurre para enunciar y representar la pobreza y la subjetividad popular.

En primer lugar, encontramos una cinematografía que intenta construir 
un relato crítico que tiene por objetivo apostar por un discurso que se propone tensionar los mecanismos de dominación y exclusión social a los que comúnmente se ven sometidos los pobres. Películas como A la sombra del sol y Hechos consumados son ejemplo de este tipo de cinematografía crítica, que tiene en su horizonte político evidenciar ciertas problemáticas, como es la problemática de la justicia popular en la película de Caiozzi y Perelman; o cuestionar el neoliberalismo y su tendencia a privatizar la vida social en la cinta de Luis Vera.

En estas cintas la dificultad para elaborar y evidenciar una cinematografía crítica pasa por la complejidad del contexto dictatorial que divide a Chile en dos campos de discursos contrapuestos. Por un lado, está el eje dominante y victimario que encubre su totalitarismo de corte refundacional, con la promesa de una racionalidad constructiva que disfraza la arbitrariedad de su violencia destructiva (física y simbólica), y que establece el horror como herramienta que opera disciplinariamente como de una verdad obligada (Richard, 2000). El otro eje, dominado y victimado, "aprende traumáticamente a disputarle sentidos al habla oficial, hasta lograr rearticular las voces disidentes en microcircuitos alternativos que impugnan el formato reglamentario de una significación única" (Richard, 2000: 61). Es en estos microcircuitos donde esta cinematografía logra establecer una discursividad crítica que tensiona alguno de los aspectos de la realidad dictatorial, pero que no logra o mejor dicho no puede llevar a cabo el ideal del "arte crítico, que en su formulación más general, se propone concientizar acerca de los mecanismos de dominación con el fin de convertir al espectador en un actor consciente de la transformación del mundo" (Rancière, 2011: 59). Sin embargo, a pesar de esta dificultad producto de la violencia terrorífica y censuradora con la actuaron los militares después del golpe de Estado pinochetista, estas dos películas logran dialectizar una legibilidad de la historia en un momento de horror y destrucción de la condición humana, una legibilidad dialéctica que se positiva a través de una cinematografía que no pretende esencializar o idealizar a los sujetos populares y su pobreza, sino que intenta volverlos sujetos de su propia historia que llevan sus propios asuntos, ya no desde un lugar único y soberano, sino con una serie 
de matices, contradicciones y conflictos.

La segunda tendencia se caracteriza por un cine que se construye desde una mirada autoral y hermética que está representada por la película El zapato chino. Aquí el recurso para eludir la censura dictatorial es una discursividad inescrutable en cuanto diégesis y narración. El hermetismo autoral "se entiende como una resistencia a confrontar los enunciados con la exterioridad del sentido común" (Corro, 2012: 77). La película de Cristián Sánchez se configura, entonces, como un intento por trazar un camino que pone en el centro del relato el encierro de los protagonistas en sí mismos, lo desolado de una ciudad en Estado de sitio, el interior de una subjetividad popular autosecuestrada en su propia indolencia, y todo ello en la clave de una alegoría hermética, que pretende conjugar no tanto una "retórica de lo simbólico, sino la acumulación de obsesivas posiciones de sentido" (Lindner, 2014:20).

La alegoría y su hermetismo se materializan en El zapato chino como expresión estética que hace de la subjetividad popular - la de Manuel el taxista y la de Marlene la joven que ha emigrado del campo a la ciudad para trabajar en un burdel-, una historia sumergida en un "fuera de lugar", donde los personajes vagan de un lugar a otro, de una casa a otra, de un motel a otro, sin hallar un sitio donde establecer su lugar en el mundo (De los Ríos, 2014). Este "fuera de lugar" ha sido leído como "un nomadismo avant-la-lettre (Rufinelli, 2007: 17); o como alegoría política que se localiza "en las elipsis, en el uso del fuera de campo, en la disociación entre lo que se dice y lo que vemos o dejamos de ver" (De los Ríos, 2014: 178); pero también puede ser leído como la expresión enmascarada de una cinematografía fragmentaria y melancólica, enfrascada en una rigidez cadavérica.

Finalmente, encontramos una cinematografía que podemos clasificar como comercial, representada por Sussi y Todo por nada, que distribuye representaciones que fabrican afirmaciones sobre la pobreza, que autorizan visiones acerca de ella, e instalan imaginarios que ayudan a clasificar, describir y entender la pobreza como una categoría cultural que, en última instancia, deja entrever una suerte de porosidad de la representación en cuanto mímesis, que en sus diversos registros y estéticas, evidencian que la representación 
fílmica del pobre es siempre, como señala Pierre Bourdieu (2006: 32), "una fracción dominada de la clase dominante". Este dominio se materializa, en ambas cintas, al construir un relato que hace de la mujer y su condición de precariedad social, el territorio fértil para la cosificación de lo femenino.

Bajo la hegemonía de un país clausurado por la dictadura, la estética televisiva "impone una conciencia de lo real con predominio del presente pero de un presente delgado y parcelado" (Corro, 2012: 88). En mayor o menor medida, tanto Sussi como Todo por nada, resuena con vehemencia el eco de la hegemonía televisiva como dispositivo estético-político que tiende -como en la película de Alfredo Lamadrid-a una construcción despolitiza de lo relatado. La despolitización opera en este tipo de cinematografías como un telón de fondo que contribuye, por ejemplo, en la naturalización de lo femenino como cuerpo colonizado por la pulsión masculina, o bien como dispositivo que contribuyen a legitimar socialmente la cosificación femenina como entidad domesticada. Así, en este tipo de cinematografía se hacen circular relatos que esencializan la complejidad de los actos humanos, y con ello, se "organiza un mundo sin contradicciones puesto que no tienen profundidad, un mundo desplegado en la evidencia, [que] funda una claridad feliz: las cosas parecen significar por sí mismas" (Barthes, 1999:199). En consecuencia, la condición política, entendida ésta como el conjunto de relaciones humanas en su poder de construcción y elucidación del mundo, se encuentra clausurada en este tipo de cintas, puesto que su clausura irrumpe bajo el signo de un espectáculo audiovisual, que establece como naturaleza lo que es una condición social, histórica o política.

\section{REFERENCIAS}

Aceituno, Roberto (2012). Memoria de las cosas. Santiago de Chile: Ediciones Departamento de Artes Visuales, Universidad de Chile.

Araujo, Kathya y Martuccelli, Danilo (2012). Desafios comunes. Retrato de la sociedad chilena y sus individuos. Tomo I. Santiago de Chile: LOM Ediciones. 
Barthes, Roland (1999). Mitologías. México: Siglo XXI Editores. (2001). S/Z. Buenos Aires: Siglo XXI Editores.

Blanco, Fernando (2012). Desmemoria y perversión. Privatizar lo público, mediatizar lo intimo, administrar lo privado. Santiago de Chile: Editorial Cuarto Propio.

Boron, Atilio (1999). "Intervención en el diálogo la trama del neoliberalismo: mercado, crisis y exclusión social". En Emir Sader y Pablo Gentili (Coord.) La trama del neoliberalismo Mercado, crisis y exclusión social. Buenos Aires: EUDEBA, 91-128.

Bourdieu. Pierre (2006). "Campo de poder, campo intelectual y habitus de clase". En Intelectuales, política y poder. Buenos Aires: EUDEBA, 23-42.

Bourriaud, Nicolas (2013). Estética relacional. Buenos Aires: Adriana Hidalgo Editora.

Brunner, José Joaquín. (1978). Apuntes sobre la figura cultural del pobre. Documento de trabajo $N^{\circ}$ 69/78. Santiago de Chile: FLACSO.

- (1981). La cultura autoritaria en Chile. Santiago de Chile: FLACSO.

- (1988). Un espejo trizado. Ensayos sobre cultura y politicas culturales. Santiago de Chile: FLACSO.

Brunner, José Joaquín, Barrios, Alicia. y Catalán, Carlos (1989). Chile: transformaciones culturales y modernidad. Santiago de Chile: FLACSO.

Corro, Pablo (2012). Retóricas del cine chileno. Ensayos con el realismo. Santiago de Chile: Editorial Cuarto Propio e Instituto de Estética Pontificia Universidad Católica.

Deleuze, Gilles (1987a). Foucault. Barcelona: Paidós. (1987b). La imagen-tiempo. Estudios sobre cine 2. Barcelona: Paidós.

De los Ríos, Valeria (2014). "El zapato chino como alegoría política, una aproximación”. En Claudia Barril, Pablo Corro y José M. Santa Cruz (eds.) (2014). Audiovisual y politica en Chile. Santiago: Editorial ARCIS, 176-181.

Didi-Huberman, Georges (2015a). Remontajes al tiempo padecido. El ojo de 
la historia 2. Buenos Aires: Editorial Biblos.

(2015b). Ante el tiempo. Historia del arte y anacronismo de las imágenes. Buenos Aires: Adriana Hidalgo Editora.

- (2014). Pueblos expuestos, pueblos figurantes. Buenos Aires: Manantial.

Donoso, Karen (2013). 'El 'apagón cultural' en Chile: políticas culturales y censura en la dictadura de Pinochet 1973-1983”. En Outros Tempos, vol. 10, $N^{o}$. 16, 104-129.

Esposito, Roberto (2011). Bíos. Biopolitica y filosofía. Buenos Aires: Amorrortu Ediciones.

Foxley, Alejandro (1982). "Experimentos neoliberales en América Latina". Estudios CIEPLAN N $N^{\circ}$ 7, número especial, 5-132.

Gallardo, Francisco (2007). “A La sombra del sol y la penumbra de los tiempos de la historia". Estudios Atacameños: Arqueología y Antropología Surandinas $\mathrm{N}^{\circ} 33,125-132$.

Héritier, Françoise (2007). Masculino/Femenino II. Disolver las jerarquías. Buenos Aires: Fondo de Cultura Económica.

Hurtado, María Luz (1985). La industria cinematográfica en Chile: límites y posibilidades de su democratización. Santiago de Chile: CENECA.

Krotz, Esteban (2002). La otredad cultural. Entre utopía y ciencia. Un estudio sobre el origen, el desarrollo y la reorientación de la antropología. México DF: Fondo de Cultura Económica.

Lewis, Oscar (1980). Antropología de la pobreza. México DF: Fondo de Cultura Económica.

Lindner, Burkhardt (2014). "Alegoría”. En Michel Opitz y Erdmut Wizisla (Eds.) Conceptos de Walter Benjamin. Buenos Aires: Editorial Las cuarentas, 17-82.

Mayol, Alberto y Ahumada, José Miguel (2015). Economía politica del fracaso. La falsa modernización del modelo neoliberal. Santiago de Chile: El Desconcierto Editores.

Mouesca, Jaqueline. (1998). Plano secuencia de la memoria de Chile. Veinticinco años de cine chileno (1960-1985). Madrid/ Santiago de 
Chile: Ediciones del Litoral.

Mouesca, Jacqueline y Orellana, Carlos (2010). Breve historia del cine chileno. Desde sus orígenes hasta nuestros días. Santiago de Chile: LOM Ediciones.

Mulvey, Laura (2001). "Placer visual y cine narrativo". En Willis, Brian (ed.) Arte después de la modernidad. Nuevos planteamientos en torno a la representación. Madrid: Akal, 365-388.

Rancière, Jacques (2011). El malestar en la estética. Buenos Aires: Campo Intelectual

- (2009). El reparto de lo sensible. Estética y política. Santiago de Chile: LOM Ediciones.

Richard, Nelly (2011). La insubordinación de los signos. Santiago de Chile: Editorial Cuarto Propio.

Ruffinelli, Jorge (ed.) El cine nómade de Cristián Sánchez. Santiago de Chile: Uqbar Editores.

Ruffinelli, Jorge y Sánchez, Cristián (2007). "El deseo de desear. Una conversación con Cristián Sánchez". En Jorge Ruffinelli (ed.) El cine nómade de Cristián Sánchez. Santiago de Chile: Uqbar Editores, 49107.

Soto, Héctor (2007). La aproximación del cine a la realidad no es inocente. En J. Ruffinelli (ed.) El cine nómade de Cristián Sánchez. Santiago de Chile: Uqbar Editores, 217- 221.

Turner, Víctor (1988). El proceso ritual. Estructura y antiestructura. Madrid: Taurus.

\section{Filmografía}

A la sombra del sol (Película). Dirección, Silvio Caiozzi y Pablo Perelman (1974), (67 min.), $35 \mathrm{~mm}$. Color.

El zapato chino (película). Dirección, Cristián Sánchez (1979), (71 min.), 16 mm. Blanco y Negro.

Hechos Consumados (película). Dirección Luis R. Vera (1986), (109 min.), 16 
$\mathrm{mm}$. Blanco y negro.

Sussi (película). Director, Gonzalo Justiniano (1988), (100 min.), $35 \mathrm{~mm}$. Color.

Todo por nada (película). Director, Alfredo Lamadrid (1989), (100 min.). 35 $\mathrm{mm}$. Color. 